turnips and carcinoma in man. We have had no opportunity of investigating the nature of the evidence on which their opinions are based and we are therefore debarred from commenting upon it. It is otherwise with the published work of Gaylord, Woronin, Nawaschin, Behla, and Podwyssozki whom the writers have quoted. These investigators have not established either that cancer is an infective disease or that an analogy exists between the morbid processes of "fingerand-toe" disease and carcinoma any more than do the contribitions of von Leyden and others to the same subject. If the writers have succeeded where earlier workers on the plasmodiophora have failed it is all the more necessary for them to supply a convincing demonstration of the fact. Until they do so they cannot claim to have done more than to have clescribed and interpreted another cell inclusion in carcinoma and the serious criticisms of von 'Tubeuf, Lubarsch, and von Hansemann will still remain unanswered, as will the more general criticisms which have been passed upon the cell inclusions of cancer generally. We trust that workers with such a desire to be objective as Dr. Robertson and Mr. Wade will not only be able to solve the many contradictions in the literature on the relation of the plasmodiophora to cancer and cell inclusions generally but that they will succeed in establishing their thesis.-ED. L.

\section{CERTIFICATES FOR MIDWIVES AND THE OBSTETRICAL SOCIETY OF LONDON.}

\section{To the Editors of THE LANCET.}

SIRs,-In your issue of Jan. 28th there is a report of an inquiry held by the Central Midwives Board into a charge against a certified midwife of signing false certificates. As there is a passage in that report which is in danger of creating an impression contrary to fact and cletrimental to the reputation of the Obstetrical Society of London, may I, as the witness whose evidence is concerned, be allowed a word or two by way of explanation? The statement that I made was to the effect that the Obstetrical Society of London some ten years ago was in the habit of occasionally accepting a certificate of attendance upon a smaller number of cases than the regulations required on the understanding that a supplementary certificate would be furnished before the day of examination showing that the candidate had by that time completed the required number. This is, of course, a very different thing from conniving at a false certificate, which is what your readers would naturally suppose from your report to be what the Obstetrical Society did.

$$
\text { I am, Sirs, yours faithfully, }
$$

A. HANNAM

Jan. 30th, 1905

Secretary and Librarian of the Obstetrical Society of London.

\section{OVARIOTOMY IN A COTTAGE.}

\section{To the Editors of THE LANCET.}

SIRS,--The unusually early age of the patient, who was only $11 \frac{1}{2}$ years old, impels me to report this case. I was called in to see the patient, a little girl, by Dr. R. McCandless of Rathfriland. She had a temperature of $101^{\circ} \mathrm{F}$. and was suffering from colicky pains in the lower part of the abdomen with gastro-intestinal disturbance. These symptoms she had complained of more or less for the previous five months, but they had become much aggravated during the last few days with the elevation of the temperature. There was an obvious fulness of the hypogastrium and a tumour was plainly felt extending above the umbilicus, dull, fluctuating, very tense, and with clearly defined outlines. There was no dulness in the flanks and the tumour was unaltered on evacuating the bladder. There was a tuberculous family history and it was only this fact, coupled with the youth of the patient, who had shown no signs of early puberty, that cast any doubt upon the diagnosis of a frank ovarian cyst. I urged an immediate operation as the patient was in a serious condition but it was impossible to secure an experienced surgeon as her people were of very humble means and lived far away from any hospital, so that I had to undertake it myself. I did so with some diffidence, as neither the surroundings nor our equipment were ideal, but I had the advantace of valuable assistance from my friend Dr. J. A. D. Radcliffe and Dr. McCandless chloroformed the patient for us two days later. (In opening the abdomen the tumour was found beneath the omentum with smooth surface, very tense, and filling the lower half of the abdominal cavity. On puncturing with trocar about one and a half pints of slightly blood-stained fluid escaped. 'The cyst was then found to spring from the left ovary, a few recent adhesions to the intestines being easily separated by the fingers. The appendages on the left side were removed along with the tumour. The right ovary appeared healthy and was left. On opening the tumour a mass of hair presented, revealing a dermoid cyst, and thus, I suppose, accounting for its development at so early an age. I would be glad to know, however, if such cases are at all common. The patient stood the operation well, although it was rather prolonged (one and a half hours), and made a good recovery. I removed the stitches ten days later and the wound was quite healed. The little girl is now running about and seems perfectly well.

I am, Sirs, yours faithfully, J. HOPE REFORD, M.D. R.U.I.

Banbricge, co. Down, Jan. 26th, 1905.

\section{SUNSHINE IN GUERNSEY.}

\section{To the Editors of THE LANCET.}

Sirs,-It does not seem to be as widely known as it should be that this island is a highly favoured place as regards the large amount of sunshine it enjoys. A reference to the table given beneath will show that in 1904 Guernsey holds the record by 211 hours over Hastings, the sunniest town in England for that year:-

\begin{tabular}{|c|c|c|c|c|c|c|c|}
\hline & & & Hours. & & & & Hours. \\
\hline Gue & ... & ... & 1926 & Cornwall ... & $\ldots$ & ... & 1660 \\
\hline Jer & $\ldots$ & $\ldots$ & 1866 & Devonshire & $\ldots$ & $\ldots$ & 1634 \\
\hline Hastings ... & $\cdots$ & & 1715 & London ... & $\cdots$ & $\cdots$ & 1328 \\
\hline
\end{tabular}

I am, Sirs, yours faithfully,

HY. DRAPER BISHOP,

Jan. 28th, 1905. Medical Officer of Health, States of Guernsey.

\section{ATMOSPHERIC CONDITIONS AND THE OCCURRENCE OF CEREBRAL HÆWORRHAGE.}

To the Editors of THE LANCET.

Sins,--I am much interested in Dr. J. W. Russell's contribution on the above subject in I'HE LANCET of Jan. 28th, p. 222, as since Dr. R. Hensleigh Walter and others so strongly suggested the influence of climatic conditions in deciding the onset of an attack of cerebral hæmorrhage I have been endeavouring to ascertain if any statistical proof could be obtained in favour of the belief which exists in the minds of many practitioners. The material at my disposal consists of a large number of death certificates and meteorological observations taken by myself. Only about 15 per cent. of death certificates give the duration of illness or date of attack. I thought it might be interesting to see if deaths from apoplexy were more common under high or low pressure. Dealing first with the returns for Bath for three years-121 deaths-I found that 64 per cent. of the deaths took place when the atmospheric pressure was akove the average of the three years, $29 \cdot 84$ inches, but the pressure was above the average on 57 per cent. of the days of these three years.

Dr. Russell takes the average pressure of 12 years as $29 \cdot 376$ inches ; this, I suppose, is the uncorrected reading of the barometer, otherwise it seems low. He says that a larger number of cases occurred on days on which the barometric pressure was above the average than on those when a pressure below the average was recorded, the proportion in the total number of cases being almost exactly as 5 to 4 . Singularly enough in the three years 1901-03, the days on which the pressure was above the average compared with days on which the pressure was below the average were almost exactly as 5 to 4 . If the same ratio obtained during the 12 years 1891-1902, Dr. Russell's cases must have been fairly evenly distributed, but days of high pressure being more frequent than days of low pressure attacks of cerebral hæmorrhage are apparently more common on days of high pressure. Anyone wishing to confirm these figures can 